\title{
Legal Analysis on the Implementation of Good Corporate Governance in State Owned Enterprises
}

\author{
Edson Yudisthira ${ }^{1}$, Megawati Barthos ${ }^{2}$ \\ \{Edson.yudisthira@gmail.com¹, megawati_barthos@borobudur.ac.id²\} \\ Student Program Doctor of Law Universitas Borobudur, J1. Pemuda, RT.1/RW.3, \\ Rawamangun, Kec. Pulo Gadung, DKI Jakarta 13220, Indonesia ${ }^{1}$, Faculty of Law, Universitas \\ Borobudur, Jakarta, Indonesia ${ }^{2}$
}

\begin{abstract}
State owned enterprises (SOE) are some of the economic agents in the national economic system where the entire or most of their capital originated from the designated nation wealth and play some roles in providing goods and/or services needed to provide nation-wide prosperity. State owned enterprises has taken more roles to pioneer business sectors that private enterprises have not been interested in, balancing the power of large private enterprises. Studying the principles, definition and application of GCG the Constitutional Law of the Limited Enterprises, including the management of central and subsidiary enterprises can become an attempt to create a measured work climate, effective and efficient in order to ensure that the management can function well and avoid the risk of authority abuse, transparency and bribery. There for to implement the principles of GCG, the main requirement is that the law must be applies firmly, optimal punishments must be given to all who tries to play with the rules of the law.
\end{abstract}

Keywords: State Owned Enterprises (BUMN); Corporate Governance; Good Corporate Governance (GCG); Enterprise Management Principles; Transparency

\section{Introduction}

The talk of Corporate Governance system has become important in current business world, especially when linked with the law of the enterprise, the concept has become a fundamental issue. Corporate administration can be perceived as a bunch of rules which oversee the connection between partners, the administration of the organization, loan bosses, government, representatives just as other interior or outer party in importance with their freedoms and commitments. In another words, it is a framework that oversees and controls the organization. In the end, GCG aims to create added value for every party involved by defining the right and responsibility connected to goal achievement which has been determined systematically, formulated as a set of rules which controls every part in a corporation to achieve its goal.

GCG always ends on two things, the division and implementation of the task. Division of the task surely is based on sufficient criteria, based on individual competence, experience, willingness to change and develop oneself and also the readiness to carry out the duties given. 
Meanwhile the criteria in duty implementation is only responsibility. Every party must carry out their assigned duties responsibly and must be ready to be held accountable, that is the unnegotiable demand of GCG principle. Failure to implement GCG may result in several things such as failure of the company to fulfill its obligations, misuse of funds and stock diversion. Those results happen because the parties did not carry out their duties responsibly which can destroy the company. That condition can make the company inefficient and suffer a loss or even bankruptcy.

The importance of GCG implementation must be realized by all party, as mentioned in the Service of State Owned Enterprises Regulation No. PER-01/MBU/2011 on August 1, 2011 in regards to GCG in state possessed endeavors. The GCG standards suggested comprise of:

a. Transparency, which is the straightforwardness in executing the direction and sharing material data applicable to the organization;

b. Accountability, which is the clearness of capacity, execution and obligation of a unit to ensure powerful organization the board;

c. Responsibility, which is the consistence between the administration of an organization with guidelines and solid helpful standards;

d. Independency, which is a condition where an organization is overseen expertly with practically no conflict of interest and impact or tension from any party with guidelines and sound corporate standards

e. Fairness, which is reasonableness and fairness in satisfying the privileges of partners dependent on arrangements and guidelines.

State owned enterprises according to the regulation No. 19 in 2003 is an enterprise where entirely or partially of the capital is state owned. They are established to run important production branches and manage strategic natural wealth concerning the livelihood of the people. State owned enterprises plays a role in producing goods or services need to bring prosperity to the people. That role is realized by economic activity on almost every sectors from agriculture, manufacture, mining financial and telecommunication. In the context of realizing that role requires the state owned enterprises to fulfill common governance conditions. The question is, has current state owned enterprises comply with GCG? It can be briefly concluded that not all state owned enterprises can fulfill the aspects of governance in their management. This can be proven from the findings made by the financial inspection office which shows the disobedient against regulations in managing the state financials and the shortage of revenue when managed by a third party resulting in a loss. That condition will be a loss for the state caused by a weak internal control system.

This shows why internal audit unit is essential for most state owned enterprises which has yet to show capable competence in governance because the control management did not make a Statement of Corporate Intent, management contract and has yet to decide, Key Performance Indicator for every division or unit as well as personal. As a result, the function for implementation and responsibility of the organization has become ineffective. Statement of corporate intent is crucial for the focus of the enterprise which aimed toward the state assignment in order for the enterprise to run well. Management contract is important in viewing the improvement and capability of the board of directors and other state financial officers up to the management level. A good state owned enterprise has a very measured management contract. Key performance indicator is important to see each capacity to find out whether the assignment given from the top management all the way to executor possess the capability, qualification and level of acceleration in doing the job. 


\section{Methodology}

The method of research used is juridical normative with regulatory approach which is conducted by seeing every regulation and constitution related to the law issue at hand. Beside juridical normative, research will also be done by using juridical empiric through researching the principles of law. Based on the type of research used, the source of the law materials is secondary data gained from literature resources which covers the primary, secondary and tertiary law. The technique for gathering law material used is library research to obtain theoretical concept, doctrines, opinions or conceptual thoughts in relevance with the research in form of constitutional regulations, books, written literature and other works. The type of approach used will be of regulatory and comparative approach. The analysis on law materials obtained will be done qualitatively by studying and researching written regulations descriptively, argumentatively and systematically so that it not only shows data but also expose the reality on implementation of GCG in state owned enterprises as an analysis.

\section{Results and Discussion}

The Forum for Corporate Governance in Indonesia (FCGI) specifies corporate administration as a bunch of guidelines that arrange the connection between partners, the executives, lenders, government, worker just as other inner and outside party on their privileges and commitments, or in another term, a framework that points and controls an organization. The motivation behind corporate administration is to make an additional incentive for each party. Centre for European Policy Study (CEPS) states that GCG is an entire system which is formed starting from rights, process and control whether inside or outside the management of the company. Indonesian organization of corporate administration (IICG) states that GCG is an interaction and construction utilized in running the organization, with the principle motivation behind expanding the worth of partners in the long haul and as yet focusing on different partners. Corporate governance also requires a structure of tools to achieve the goal and supervision of performance.

Cadbury Committee states corporate governance as a system that aims and controls a company with the purpose of achieving balance between power and authority needed by the company to ensure its sustainable existence and responsibility towards the stakeholders. This is related to the authority rules of the owner, director, manager, stakeholder and others. Decision of the minister of state owned enterprises No. KEP 117/M-MBU/2001 explains GCG as a process from the structure used by the organ of state owned enterprises to increase the success of the business and corporate accountability to achieve stakeholder value in the future by paying attention to the needs of other stakeholders, based on regulations and ethical value.

Ernest and Young states corporate governance as a collection of mechanism linked together which consist of institutional stakeholders, board of directors and commissioners, managers who are paid based on their work performances, a market to control the company, structure of ownership, financial structure, related investors and product competition. As explained above, corporate governance also mean something related to effective decision making based on company culture, etiquette, scoring system, business process, policy and organizational structure whose goal is to encourage growth in company performances, more efficient management of resources and accountability to stakeholders and shareholder. The importance of good corporate governance in a company is due to these reasons: 
a. Investors will have more faith in companies with GCG since investor often placed GCG as one of the main criteria aside from financial performance and growth potential.

b. There is an indication of a connection between economic crisis in Asian countries during the twentieth century with the slow moving implementation of GCG by companies in those countries. The weak implementation of GCG in Asian countries can be seen by the existence of family management, protection policy, government intervention, bribe and corruption.

c. The application of FCF has become a need in market internationalization including the modernization of financial and capital market so investors are willing to invest.

d. The principle of GCG has given grounds for the value development of the company in accordance with present growth of business landscape which value the independence, transparency, professionalism, social responsibilities and other things.

In implementing GCG in Indonesia, the national committee of GCG policy has formulated a general guidance on the implementation of GCG which states the intentions and purposes of GCG implementation as follows:

a. To help the accomplishment of congruity of the organization through administration which depends on straightforwardness, responsibility, obligation, independency just as reasonableness and fairness.

b. To help the utilization of capacity and autonomy of each organization organ like the leading group of magistrates, chiefs and comprehensive gathering of investors.

c. To energize investors, individuals from the board magistrates and chiefs to decide and complete their activities dependent on high virtue and submission toward guidelines.

d. To energize mindfulness and social obligation to the general public and climate maintainability around the organization

e. Optimizing organization an incentive for investors and as yet focusing on other concerning parties.

f. Increasing seriousness worth of the organization both broadly or globally to support market trust which will help contributing course and proceeded with public financial development.

The decision of the minister of state owned corporations number KEP-117/M-MBU/2002 explains the purpose of implementing GCG in state owned corporations as follows:

a. To maximized the value of state owned corporations by increasing the principle of openness, accountability, trustworthiness, responsible and fair so that the corporation will have strong competitiveness nationally and internationally.

b. To boost professional management of the state owned corporations, transparency and efficiency as well as increasing independency of unit.

c. To boost the unit in making decision and acting based on high moral value and obedience towards regulations with also the awareness for the social responsibility of state owned corporations to the stakeholders and the sustainability of the environment surrounding the corporations.

d. Increasing the contribution of state owned corporation in national economy.

e. Succession of the privatization program.

According to the forum of corporate governance in Indonesia (FCGI) there are five important main principles in corporate governance which are: 
a. Transparency, the accurate reveal, in time and transparency on important points on the performance of the company, ownership and concerning party.

b. Accountability, is meant as a principle which implicate on the legal obligation of the directors, signaled to have a relationship based on trust with the shareholders and the company. Directors may not have personal interest in making decision or acting actively based on overall information. The principle of accountability made clear on the assurance that the company will respect the rights of stakeholders, there is an opportunity for stakeholders to receive compensation upon the violation of their rights, the availability of achievement development mechanism for relevant stakeholder and access for all party on relevant information.

c. Responsibility, this principle covers things related to the fulfillment of social obligation by the company as part of the society. Company can fulfill its responsibility to shareholder and stakeholder according to the law and regulations and they should uphold the laws such as regulations on workforce, tax, health, forbidden monopoly and unhealthy business competition. In line with that, board of commissioners as supervising unit must conduct their job effectively on the directors who are obligated to be responsible for the policies made in the company which is a requirement that must be uphold by the directors.

d. Independency, a condition where the company is free from influences or pressure from other parties which are not compliant with the corporation mechanism. This principle also obligates the company to have internal policies according to regulations and existing laws. Independency must be carry out so that the company is not easily influenced by parties from inside or outside.

e. Fairness, to guarantee the freedoms of investors including the minority investors and unfamiliar investors just as insuring commitments with investors.

Rights of the shareholders must be protected according to the GCG principles of the Organization for Economic Cooperation and Development (OECD) are:

a. Basic rights consisting of:

1. Ensuring the registration method for the shares,

2. Transferring their shares

3. Receiving information regularly and on time

4. Participating and voting during the general meeting of shareholders

5. Choosing members of commissionaires and directors

6. Receiving profit portion from the company

b. Shareholders have the rights to participate, receive sufficient information, making decisions related to the fundamental changes of the company such as authorization to add shares and exceptional transaction to influence sales result.

1. Shareholders must possess the opportunity to effectively participate in voting in the meetings of shareholders and be provided information on the rules including how to vote in the meetings

2. Capital structure and rules that allow certain shareholder to gain an unbalance level of control with ownership of shares must be disclosed

3. The market to control the company must be made to function effectively and transparently.

4. Shareholders, including institutional investors must consider the cost and advantage of using their rights 
Other than the above basic rights, GCG also make sure equivalent treatment on all investors including unfamiliar investors and minority investors, for example :

a. All shareholders with the same level of investments must be treated equally,

b. Insider trading and misuse of authority from the inside must be prohibited,

c. Member of the commissioners and directors must disclose every interest in the form of debt on transaction or any issues concerning the company.

In the general explanation of regulation No. 19 in 2003 on state owned corporations chapter VI paragraph II states that it was made to fulfill the development vision of state owned corporations in the future and placing principles on good corporate management. More on paragraph III it is stated that it provides a rule that can be used as a guidance to manage and supervised based on efficient and productive principles to increase the performance and value of the state owned corporations from being exploited beyond the good managerial principles. From the general explanation, the regulation provides rules to be used as a guideline to manage a corporation well based on principles of GCG which are transparency, independency, accountability, responsibility and fairness.

Aside from following the regulation no. 19 above, the state owned corporations also comply regulation no. 40 in 2007 on the limited corporations. This is shown on chapter 11 of regulation No. 18 in 2003 which states that all requirements and principles applied for limited corporations also applied for regular corporation. Therefore, it is similar that both the regulation no. 19 in 2001 on state owned corporations and regulations no. 40 in 2007 has accommodate how to manage the corporation properly. The implementation if GCG based on Chapter 2 verse 1 of the decision of minister of state owned corporations no. KEP $117 / \mathrm{MBU} / 2002$ regarding the use of GCG in state owned corporations. In order to achieve good quality in implementing GCG, the minister had written a letter No. SE-14/MBU/2010 which informs that:

a. The quality for implementing GCG in state owned corporations must be a priority of key performance indicator in the yearly management contract so that it becomes one of the element in system reward and recognition in managing and supervising the state owned corporations.

b. Directors and commissioners/board of supervisors is expected to have a program which is clear and aimed to achieve the performance target of GCG based on KIP and written in RKAP.

As an attempt to synchronized the law renewal in limited corporation and state owned corporation, also viewing dynamic and competitive development of the business world, to further increase the application of GCG, the minister of state owned corporations has made adjustments to the decision of minister number KEP-117/M-MBU/2002 by announcing regulation of the minister No. PER-01/MBU/2011 which states firmly that good management is the principles that based a certain process.

The principles of good management in the regulation includes transparency, which is receptiveness in dynamic interaction and uncovering material data pertinent to the organization. Responsibility, which is the clearness of capacity, application and responsibility of the unit to guarantee viability. Obligation, which is the consistence of the organization with guidelines and solid corporate standards. Independency, which is a condition where the organization is run expertly without any conflict of interest and impact/tension from any party not as per the guidelines and sound partnership standards. Decency, which is equity and fairness in satisfying the privileges of stakeholder as written in the agreement and regulations.

It is explained further in chapter 4 of the regulation of minister of state owned corporations that the principles of GCG in state owned corporations are: 
a. Optimizing the corporation value to give it strong competitiveness nationally and internationally so it can maintain its existence and survive to achieve its goals and purposes.

b. Encourage the managing of state owned corporations professionally, efficiently and effectively while also empowering the function and increasing the independency of company unit.

c. Encouraging company unit so that in making decision and implementing it is based on high moral value and compliance toward regulations and awareness on the social responsibility for stakeholders as well as the sustainability of its surrounding environment.

d. Increasing contribution in the national economic

e. Increasing proper climate for national investment.

\section{Conclusion}

In the act of executing GCG, there are various records that should be held by the organization to guarantee the execution of GCG standards in all parts of corporate administration, including the organization's articles of affiliation, board manuals of the Board of Directors and Commissioners, hazard the executives rules, inward control framework, revealing component for supposed abnormalities in the organization (whistlebower framework), Information Technology administration, set of principles, rules for acquisition of labor and products, Key Performance Indicators and trustworthiness settlements.

SOE is a State-Owned Enterprises so that the position and main task of managing state finances should not be reduced in the slightest because the existence of SOEs is regulated and guaranteed by the 1945 Constitution of the Republic of Indonesia. SOE that occupies a strategic position must be managed with governance principles. The principle is that the company has a good level of health. The management is very strong and qualified, and all of them have excellent performance from top management to implementation level. In this way, SOE can be considered as SOE with governance so that their existence is needed by the state and their presence is beneficial to the people.

\section{References}

[1] E. E. Supriyanto, "Strategi Penerapan Kebijakan Sovereign Wealth Funds (SWFs) di Indonesia: Studi Literatur dan Studi Komparatif Oman," J. Inov. Ilmu Sos. dan Polit., vol. 3, no. 1, p. 10, Apr. 2021, doi: 10.33474/jisop.v3i1.6959.

[2] I. Wardhani and M. Barthos, "The Implementation of the Principle of Profit Sharing in the Musyarakah Financing Contract in Islamic Banks," 2021, doi: 10.4108/eai.6-32021.2306418.

[3] Y. M. Manan, "The Role of Religiosity , Halal Awareness , Halal Certification , and Food Ingredients on Sistem Purchase Integrasi Proteksi \& of Manajemen Resiko Intention Halal Food Platform Fintech peer to peer ( P2P ) Lending dan Payment Gateway untuk * Meningkatkan," Ihtifaz, vol. 2, no. 1, 2019.

[4] S. Chishti and J. Barberis, The Fintech Book: The Financial Technology Handbook For Investor, Entrepreneurs And Visionaries. John Wiley \& Sons, 2016.

[5] S. K. Shivakumar and S. Sethii, Building Digital Experience Platforms: A guide to developin Next-generation Enterprise Applications. APress, 2019. 
[6] M. H. Y. Purba, "Penguatan Perlindungan Konsumen dalam Industri Peer to Peer Lending di Indonesia,” Kanun J. Ilmu Huk., vol. 22, no. 3, pp. 547-566, 2020, doi: 10.24815/kanun.v22i3.17099.

[7] N. Desideria, "Problematika Hukum Dalam Penggunaan Financial Teknologi," Universitas Pancasakti Tegal, 2021.

[8] J. Sengupta, "Digital Banking in Asia Winning approaches in a new generation of financial services," Asia Financ. Institutions, pp. 1-89, 2014.

[9] P. Sironi, FinTech Innovation: From Robo-Advisors to Goal Based Investing and Gamification. 2016.

[10] S. A. Fitria, "Aspek Digital Lending di Indonesia," in Jurnal Legislasi Indonesia, vol. 17, no. 4, 2020, pp. 437-450. 